\title{
EXTRACTION OF HOMOLOGOUS COMPOUNDS OF CURCUMINOID ISOLATED FROM TEMULAWAK (Curcuma xanthorriza Roxb.) PLANT
}

\author{
B. Cahyono ${ }^{1, *}$, J. Ariani ${ }^{1}$, H. Failasufa ${ }^{1}$, M. Suzery ${ }^{1}$, S. Susanti ${ }^{2}$ \\ and H. Hadiyanto ${ }^{3, *}$ \\ ${ }^{1}$ Department of Chemistry, Faculty of Sciences and Mathematics, Diponegoro University, J1 Prof \\ Soedarto, SH, Tembalang, Semarang, Indonesia (50275) \\ ${ }^{2}$ Department of Agriculture, Faculty of Animal Science and Agriculture, Diponegoro University, \\ J1 Prof Soedarto, SH, Tembalang, Semarang, Indonesia (50275) \\ ${ }^{3}$ Department of Chemical Engineering, Faculty of Engineering, Diponegoro University, Jl Prof \\ Soedarto, SH, Tembalang, Semarang, Indonesia (50271) \\ *E-mail : bbc_cahyono@yahoo.com, hadiyanto@live.undip.ac.id
}

\begin{abstract}
In the herbal pharmacopeia Indonesia, curcumin is used as a marker compound in the temulawak extract. In this study, we analyzed the contents and profiles of curcuminoid constituent in temulawak extracts from three centers for the development of medicinal plants in Central Java, Indonesia; i.e Semarang Regency, Semarang City, and Karanganyar Regency. The results showed that the extracts of temulawak have yields ranging from $8.25-14.90 \%$ and the highest yield was obtained in the sample from one of the farmers in Semarang (B1). Meanwhile, total curcuminoid is ranging from 8.70-11.50\% and the highest value belongs to sample grown in Semarang (B1 and B2, in the average levels of $11.50 \%$ and $11.30 \%$ ). Variations in the composition of the curcuminoid constituent showed that curcumin is the main component in all samples. The relative contents of these compounds ranged from 68 to $76 \%$, while the demethoxycurcuminis and bisdemethoxycurcuminis were found in the range of 23 to $29 \%$, and from 1 to $3 \%$, respectively.
\end{abstract}

Keywords: Temulawak, Homologous, Compound, Curcuminoid, Central Java, Indonesia.

() RASĀYAN. All rights reserved

\section{INTRODUCTION}

Temulawak (Curcuma xanthorriza Roxb.) is an indigenous plant from Indonesia ${ }^{1}$. This plant belongs to the biggest five of Indonesian commodity medicinal plants to be developed and commercialized ${ }^{2}$. People were familiar with temulawak rhizome which used as raw materials in traditional medicine and agro-industry such as for natural food colorants ${ }^{3}$. It has been reported that chemical compounds of temulawak possess some pharmacotherapy activities such as antimicrobial, antioxidants, anticancer, and anti-inflammation ${ }^{4-}$ ${ }^{10}$. The major bioactive compound in temulawak is curcuminoid ${ }^{11,}{ }^{12}$. Curcuminoid is a class of phenolic compounds composed by curcumin (C), demethoxycurcumin (DMC), and bisdemethoxycurcumin $(\mathrm{BDMC})^{11}$. These compounds are homologous with the chemical structure as shown in Fig.-1. The activity of these components is different, for example, the anticancer activity of DMC and BDMC is higher than $\mathrm{C}^{13}$.

Several studies related to the curcuminoid content analysis of Curcuma genus have been reported in several worldwide regions and the most study was conducted on the commodity of turmeric (Curcuma longa). It also has been reported about total curcuminoid of saffron growing in India and Thailand ${ }^{14}$, ${ }^{\text {. In South }}$ Korea, total curcuminoid isolated from two species of Curcuma longa and Curcuma aromatica growing at two different areas of that country has been reported as well ${ }^{16}$. In line with those studies, we are interested in the analysis of curcuminoid isolated from temulawak growing in Central Java. Central Java- a province

Rasayan J. Chem., 12(1), 7-13(2019)

http://dx.doi.org/10.31788/RJC.2019.1213092

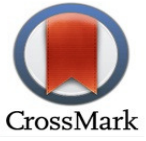


RASĀYAN J. Chem.

Vol. 12 | No. 1 |7 - 13| January - March | 2019

located on Java Island was considered as the center of herbal development in Indonesia. In the traditional medicine system, Curcuma is the most famous commodity believed in a cure for some illness inside the body ${ }^{17}$.

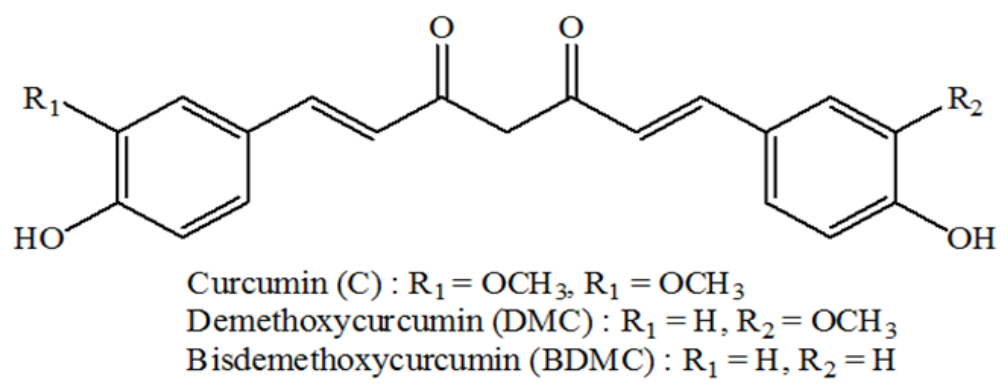

Fig.-1: Chemical Structure of three homologous compounds of curcuminoid

\section{Sample Collection}

\section{EXPERIMENTAL}

Dry simplicia of temulawak was purchased from the rhizome collectors spread in three districts of Central Java Province such as Semarang (A), Semarang City (B), and Karanganyar (C) (Fig.-2). Each district was represented by two farmer groups (1 and 2$)$ with the number of samples per group was three $(n=3)$. All samples were powdered and analyzed about its water content in order to get standardized powder simplicia.

\section{Preparation of Temulawak Extract}

$50 \mathrm{~g}$ of temulawak powder was extracted using soxhlet equipment with $96 \%$ ethanol as a solvent. The resulting filtrate was concentrated by rotary vacuum evaporator (Rotavapor® R-300, Buchi, Indonesia) to obtain the ethanol extract.

\section{Separation and Analysis of Extracts}

The temulawak extract was separated based on curcumin (C), bisdemethoxycurcumin (BDMC) and demethoxycurcumin (DMC) contents by using preparative TLC (C18 silica matrix, $20 \mathrm{~cm} x 20 \mathrm{~cm}$, Sigma Aldrich). Eluents used was a mixture of chloroform and ethanol in the ratio of 49:1(v/v). Analysis of isolated compounds (C, BDMC, and DMC) was carried out by LCMS (Mariner, Applied Biosystems, Foster City, CA) with $2 \mu \mathrm{L}$ sample injection volume.

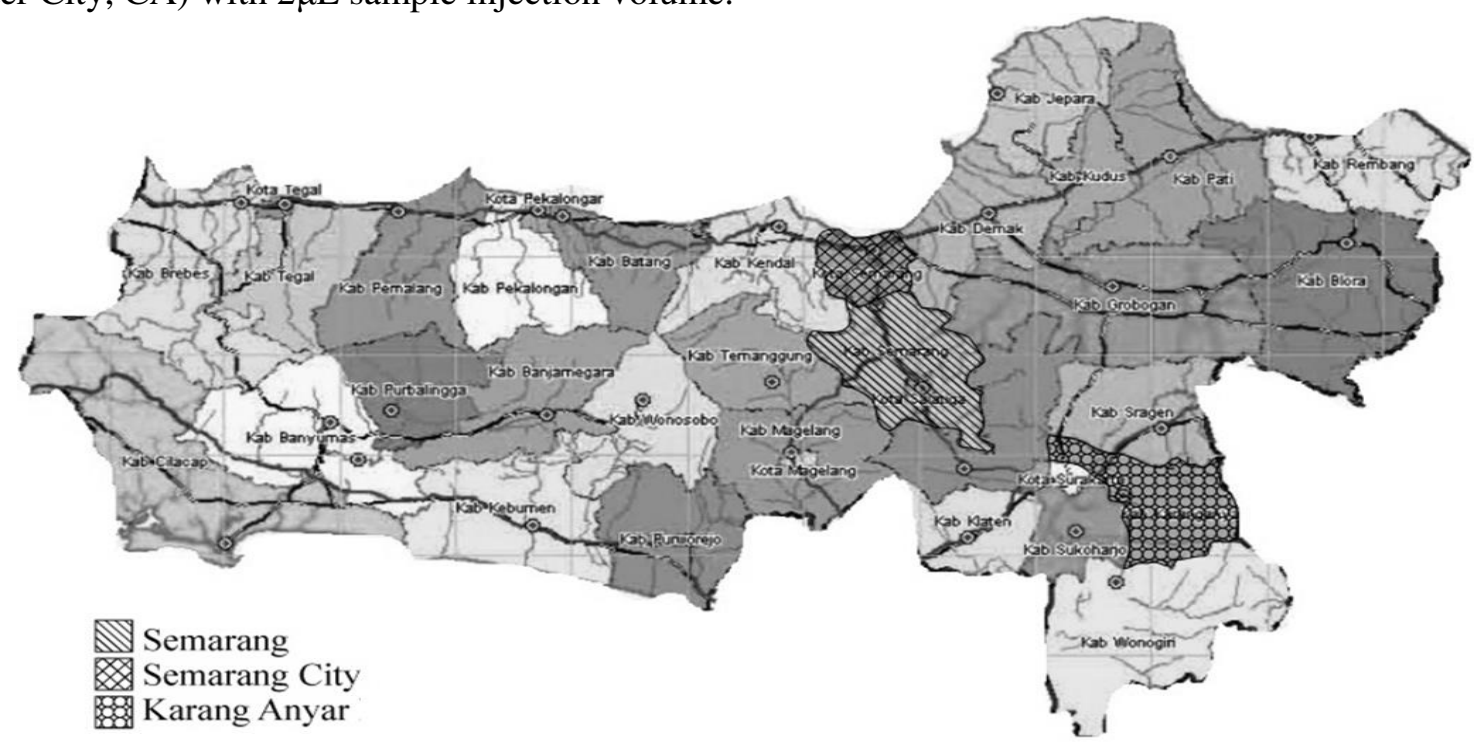

Fig.-2: Location of Temulawak sampling 
RASĀYAN J. Chem.

Vol. 12 | No. 1 |7 - 13| January - March | 2019

\section{Quantitative Analysis of Curcuminoid}

A standard curve of Curcumin was performed by dissolving standard curcumin in $96 \%$ ethanol in order to obtain a concentration of $2 \mathrm{ppm}, 3 \mathrm{ppm}, 4 \mathrm{ppm}, 5 \mathrm{ppm}$ and $6 \mathrm{ppm}$. Then each sample was analyzed using a UV-Vis spectrophotometer (UV-1601 Shimadzu) and measured the absorbance at the maximum wavelength $(425 \mathrm{~nm})$. A standard curve was constructed by plotting the concentration of curcumin (ppm) by its absorbance. Curcuminoid concentration of samples (extracts of A1, A2, B1, B2, C1, C2) was analyzed by dissolving $0.03 \mathrm{~g}$ of each extract in $10 \mathrm{~mL}$ ethanol and then diluted 80 times. The absorbance of samples was measured at the maximum wavelength $(425 \mathrm{~nm})$. Curcuminoid concentration containing in every sample was then determined by fitting the absorbance value to the linear regression of curcuminoid standard curve.

\section{HPLC Analysis of Curcuminoid}

The composition of curcuminoid of all samples (A1, A2, B1, B2, C1, C2) was analyzed using HighPerformance Liquid Chromatography (HPLC, LC-20AD, Shimadzu, USA). The concentration of each sample used was $150 \mathrm{ppm}$. The mobile phase used in this analysis was a mixture of acetonitrile, acetic acid and distilled water (50:1:49) while eluent used was methanol and $0.03 \%$ acetic acid in the isocratic system with a flow rate of $0.05 \mathrm{~mL} / \mathrm{min} .10 \mu \mathrm{L}$ of each sample was injected into the column $(5 \mu \mathrm{C} 18,150 \times 1 \mathrm{~mm}$, Phenomonex, CA, USA) with the column temperature at $27^{\circ} \mathrm{C}$. Isocratic elution was used at wavelength $425 \mathrm{~nm}$ with a flow rate of $1 \mathrm{ml}$ per minute. A full scan was performed from m/z 100 to 1200 at $140^{\circ} \mathrm{C}$.

\section{RESULTS AND DISCUSSION}

Although the composition of curcuminoid isolated from some rhizomes worldwide has been reported, none of the data has come from Indonesian curcuminoid sources. Therefore, for the first time, this study reported the composition of three homologous compounds of curcuminoid i.e. curcumin $(\mathrm{C})$, demethoxycurcumin (DMC), and bisdemethoxycurcumin (BDMC) isolated from Temulawak growing in Central Java region, Indonesia. Based on the water content analysis, all temulawak rhizomes originating from 3 different districts of Indonesia contain water less than $12 \%$ (Table 1). They have a good quality in accordance with the Indonesian National Standard of spice powder wherein the maximum allowable water content is $12 \%$ or no more than $13 \%$ according to the Indonesian Herbal Pharmacopoeia ${ }^{18,19}$.

Curcuminoid was extracted by using soxhletation method exhibited an excellent result due to the appearance of the orange-yellow color of three constituent components. After extraction, the solvent was evaporated and the brown crude was formed. Extraction yields from all samples are shown in Table 1. It depicts that yields resulting from the extraction process of this study showed variation among the farmers although they live in the same district. The extraction yields of this study ranged from 8.25 to $14.90 \%$ in which temulawak grown by farmers from Semarang City showed the highest yield of extract compared to others. The percentage of yields obtained from the extraction process can be a description of the bioactive component contained in plants ${ }^{20}$. The data suggested that differences on those total yields are closely related to the habitat and harvest condition of Temulawak plant ${ }^{21}$. It has been reported the chemical contents of plants can be influenced by sunlight intensity, soil nutrient and maturity level of the plant parts used as samples in the extraction process ${ }^{22,23}$. In this study, these factors were not considered properly when the samples collection was carried out. Although extract yields were varied in this study, the extract yield obtained from this study was highest compared to the previous study. Temulawak growing in Malaysia only possessed the extract yield of $11.8 \%$ while a South Korean researcher was only capable of getting $11.1 \%$ extract yield of Indonesian Temulawak ${ }^{4,24}$. It was noteworthy that all of the extract yields from those investigations are quite lower than extract yield standard requirement assigned by Indonesian government i.e. $18 \%$ according to the Health Ministry.

Analysis of samples using UV-Vis Spectrophotometry applied in this study is the standard analysis method for curcuminoid ${ }^{25-27}$. The wavelength of $420-430 \mathrm{~nm}$ is the typical absorbance for three homologous compounds of curcuminoid i.e. C, DMC, and BDMC. Quantitative analysis using UV-Vis Spectrophotometry usually is expressed by total curcuminoid with curcumin as standard ${ }^{28}$. Each component of curcuminoid has wavelength and molar absorptivity ${ }^{29}$. 
RASĀYAN J. Chem.

Vol. 12 | No. 1 |7 - 13| January - March | 2019

Calibration curve of standard curcumin showed a linear regression equation trendline $y=0.132 x+0.001$, with correlation coefficient close to $1\left(r^{2}=0,991\right)$. By using this equation, calculation of curcuminoid level was performed in triplicate (Table-1).

Table-1: Result of Water Content Analysis, Extract Yield, and Curcumin Concentration

\begin{tabular}{c|c|c|c}
\hline Samples & $\begin{array}{c}\text { Water content } \\
(\%)\end{array}$ & $\begin{array}{c}\text { Yield of extract } \\
(\%)\end{array}$ & Curcumin concentration (\%) \\
\hline $\mathrm{A}_{1}$ & $11.30 \pm 1.89$ & $11.23 \pm 1.12$ & $8.70 \pm 1.67$ \\
\hline $\mathrm{A}_{2}$ & $10.72 \pm 1.56$ & $10.83 \pm 1.89$ & $11.21 \pm 1.55$ \\
\hline $\mathrm{B}_{1}$ & $11.86 \pm 2.19$ & $14.90 \pm 2.28$ & $11.50 \pm 2.11$ \\
\hline $\mathrm{B}_{2}$ & $11.46 \pm 1.77$ & $13.98 \pm 1.79$ & $11.30 \pm 1.17$ \\
\hline $\mathrm{C}_{1}$ & $10.06 \pm 1.24$ & $8.25 \pm 1.59$ & $10.54 \pm 1.88$ \\
\hline $\mathrm{C}_{2}$ & $10.59 \pm 2.05$ & $8.40 \pm 1.82$ & \\
\hline
\end{tabular}

$\mathrm{A}_{1}, \mathrm{~A}_{2} ; \mathrm{B}_{1}, \mathrm{~B}_{2} ; \mathrm{C}_{1}, \mathrm{C}_{2}$ : two farmers group of Semarang, Semarang City, and Karanganyar respectively.

Temulawak samples possessed the range of curcuminoid level of $8.70-11.50 \%$ and the highest level was occupied by temulawak originally from two farmers living in Semarang City. Those rate in accordance with the data of the total yield (Table-1). Thus, it is suggested that Semarang City is the best planting area because Temulawak growing in that area gave the most extract among others. Achievement in this study, either in total yield and curcumin level was better than the previous study ${ }^{30}$. However, none of the samples from all farmers complied the standard of curcumin content (14.2\%).
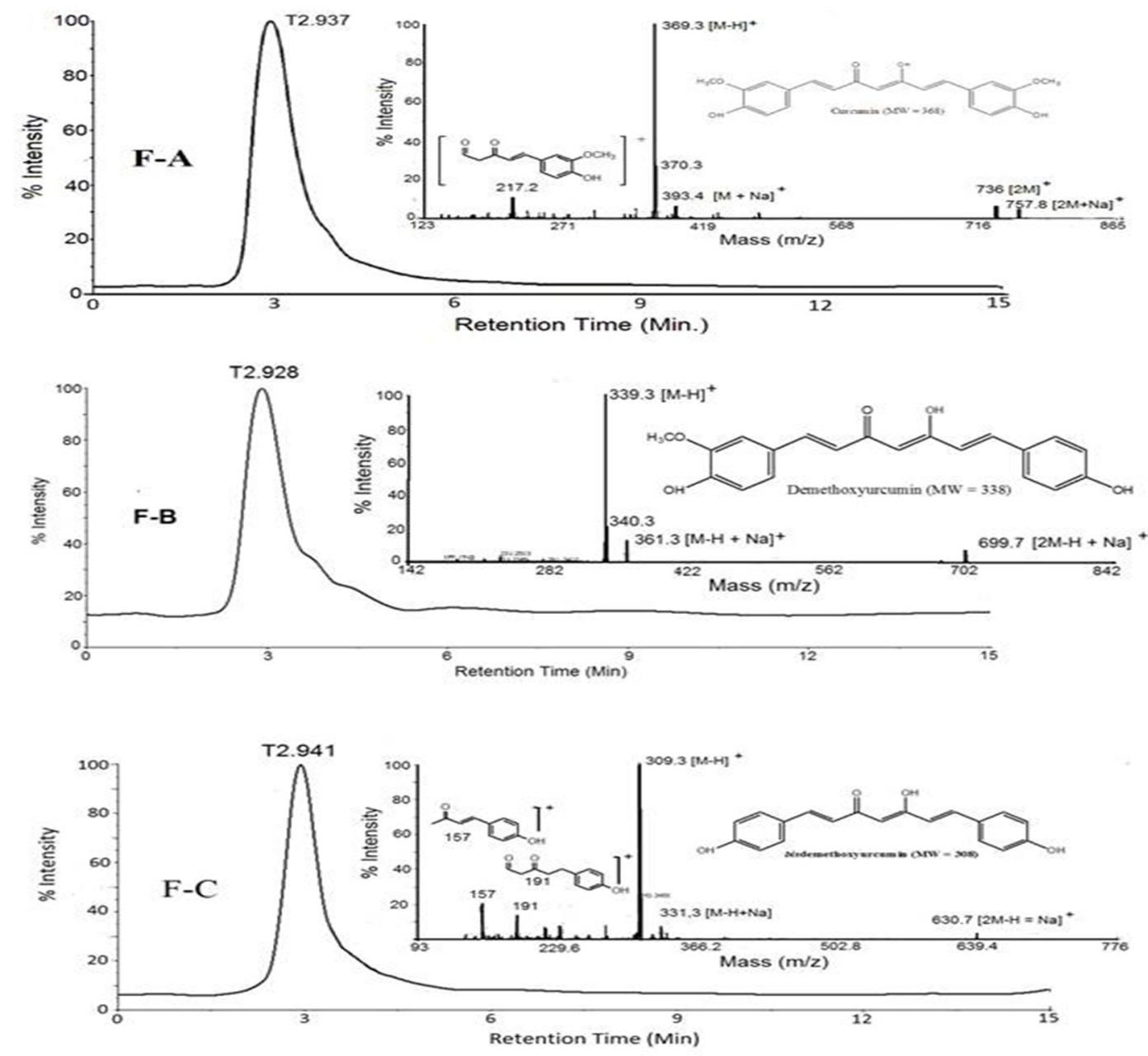

Fig.-3: LCMS Profiles of Curcuminoid Fractions (F-A:Curcumin, F-B:demethoxycurcumin, and F-C: bisdemethoxycurcumin) 
By using preparative HPLC, three curcuminoid components have been separated as curcumin (C), demethoxycurcumin (DMC), and bisdemethoxycurcumin (BDMC). The purity of each component was indicated by the presence of single peak on each fraction while the validation of chemical structure of three components was determined by their molecular weight conformity obtained from LCMS data (Figure 3). Rapid analysis of curcuminoid availability in Temulawak extract was performed using thin layer chromatography (TLC) method ${ }^{31,32}$. All of the samples depicted the same chromatogram patterns containing C, DMC dan BDMC as presented in Fig.-4.

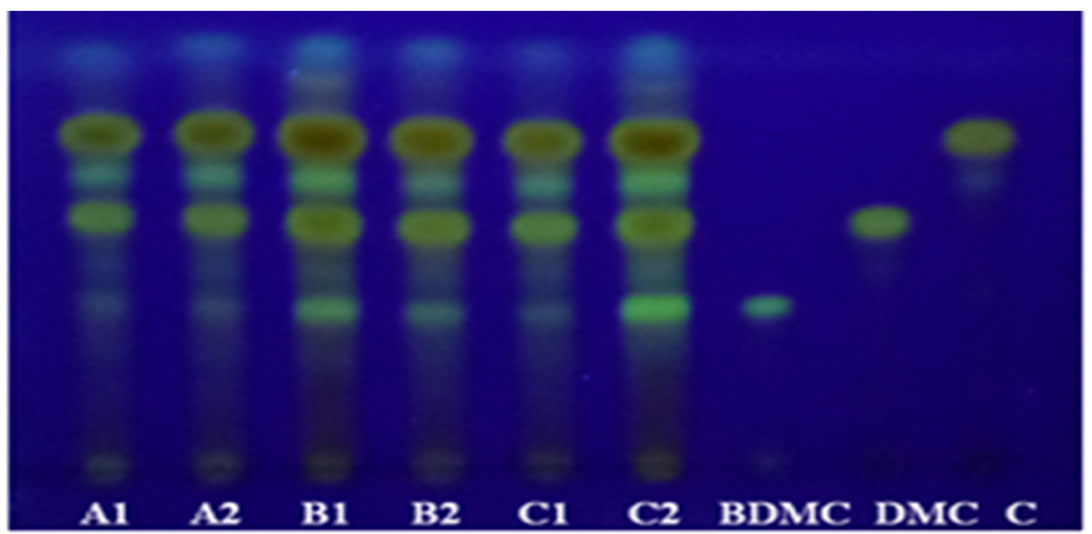

Fig.-4: TLC Patterns of Curcuminoid and Curcuminoid Standard (C, DMC, BDMC) of Temulawak samples ( $\mathrm{A}_{1}, \mathrm{~A}_{2}$; $\mathrm{B}_{1}, \mathrm{~B}_{2} ; \mathrm{C}_{1}, \mathrm{C}_{2}$ ) from two farmer groups of Semarang, Semarang City, and Karanganyar respectively
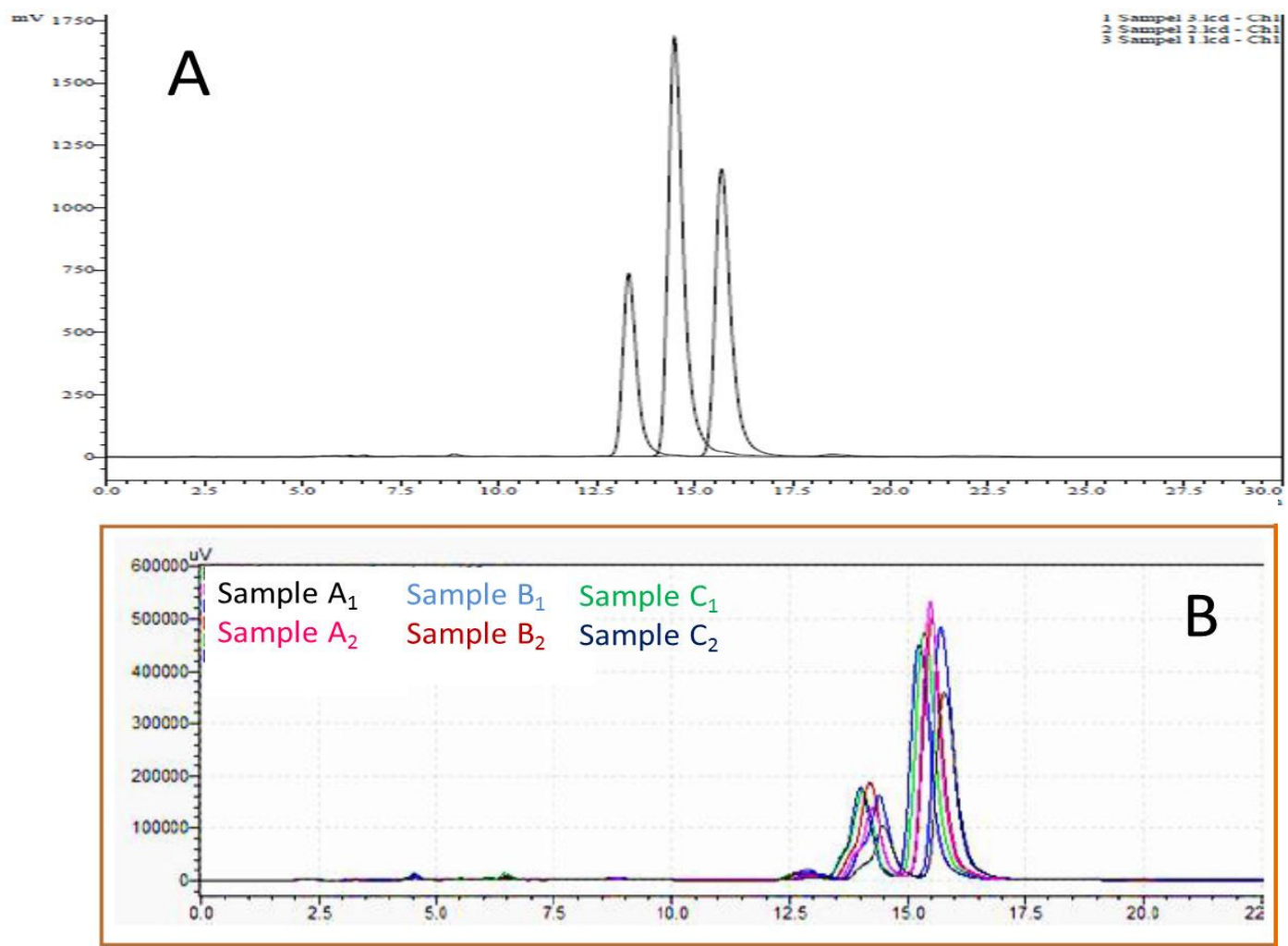

Fig.-5: Chromatogram of three homologous compounds of curcuminoid i.e. C, DMC, and BDMC (A) and the chromatogram of Temulawak extract from. $\mathrm{A}_{1}, \mathrm{~A}_{2} ; \mathrm{B}_{1}, \mathrm{~B}_{2} ; \mathrm{C}_{1}, \mathrm{C}_{2}$ : samples of two farmers group live in Semarang, Semarang City, and Karanganyar respectively (B). 
RASĀYAN J. Chem.

Vol. 12 | No. 1 |7 - 13| January - March | 2019

Furthermore, analysis of the constituent composition of curcuminoid was demonstrated in this study. It has been reported that each component of curcuminoid possessed different activities ${ }^{13}$. Curcuminoid compounds purified by preparative HPLC have retention times of 15.799 minutes, 14.486 minutes, and 12.949 minutes for C, DMC, and BDMC, respectively (Fig.-5). Data in Table-2 suggested that curcumin (C) is the major component (61.09-71.21\%) of curcuminoid compound, overtaken by demethoxycurcumin (17.09-25.00\%) and bisdemethoxycurcumin (6.3-15.29\%). The sequence of those component proportion is very common found in Temulawak sample or in another curcuma genus, such as Curcuma longa and alba ${ }^{15}$.

Table-2: Profiles of curcuminoid components from Temulawak extract originally from Central Java- Indonesia.

\begin{tabular}{|c|c|c|c|}
\hline Samples & Peak & $\%$ of the peak area & Ratio \\
\hline \multirow{3}{*}{$\mathrm{A}_{1}$} & 1 & 1.268 & \multirow{3}{*}{$1: 24: 75$} \\
\hline & 2 & 24.056 & \\
\hline & 3 & 74.676 & \\
\hline \multirow{3}{*}{$\mathrm{A}_{2}$} & 1 & 1.289 & \multirow{3}{*}{$1: 23: 76$} \\
\hline & 2 & 22.598 & \\
\hline & 3 & 76.113 & \\
\hline \multirow{3}{*}{$\mathrm{B}_{1}$} & 1 & 2.292 & \multirow{3}{*}{$2: 28: 70$} \\
\hline & 2 & 27.675 & \\
\hline & 3 & 70.033 & \\
\hline \multirow{3}{*}{$\mathrm{B}_{2}$} & 1 & 1.938 & \multirow{3}{*}{$2: 28: 70$} \\
\hline & 2 & 28.443 & \\
\hline & 3 & 69.619 & \\
\hline \multirow{3}{*}{$\mathrm{C}_{1}$} & 1 & 1.890 & \multirow{3}{*}{$2: 27: 71$} \\
\hline & 2 & 27.457 & \\
\hline & 3 & 70.653 & \\
\hline \multirow{3}{*}{$\mathrm{C}_{2}$} & 1 & 3.100 & \multirow{3}{*}{$3: 29: 68$} \\
\hline & 2 & 28.597 & \\
\hline & 3 & $6\{.303$ & \\
\hline
\end{tabular}

$A_{1}, A_{2} ; B_{1}, B_{2} ; C_{1}, C_{2}$ : two farmers group of Semarang, Semarang City, and Karanganyar respectively.

\section{CONCLUSION}

Among three districts plant area of Temulawak spread in Central Java Province-Indonesia, a sample from Semarang City possessed the most extract yield and the highest curcuminoid level; however, none of the samples compiled the criteria of Indonesian herbal farmakope on both parameters test. All samples showed the similarity of the composition sequence (from the highest to the lowest level) of three homologous of curcuminoid compounds i.e. curcumin, demethoxycurcumin, and bisdemethoxycurcumin. Thus, Semarang City is the best plant area for Temulawak sampling with regard to the curcuminoid study in the future.

\section{ACKNOWLEDGMENT}

This project was supported by the Ministry of Research, Technology and Higher Education of the Republic of Indonesia through The Fundamental Research Grant Program.

\section{REFERENCES}

1. S. Devaraj, S. Ismail, S. Ramanathan and M. Feiyam, J. Nat. Prod. Plant. Resour., 3, 67(2013).

2. Departemen Pertanian. 2007, Prospek dan Arah Pengembangan Agribisnis Tanaman Obat, Jakarta, Badan Penelitian dan Pengembangan Pertanian, hlm 5-6.

3. M. Lechtenberg, B. Quandt and A. Nahrstedt. Phytochemical Analysis., 15, 152(2014), DOI: 10.1002/pca.759

4. M. B. Kim, C. Kim, Y. Song and J. K. Hwang, Evidence-Based Complementary and Alternative Medicine., 1-10 (2014), DOI: 10.1155\%2F2014\%2F205915 


\section{RASĀYAN J. Chem.}

Vol. 12 | No. 1 |7 - 13| January - March | 2019

5. Y. Rukayadi and J. K. Hwang, Letters in Applied Microbiology., 42, 400(2006), DOI: 10.1111/j.1472765X.2006.01876.X

6. S. Anjusha and A. Gangaprasad, J. Pharmacognosy and Phytochemistry., 3, 50(2014).

7. S. W. Qader, M. A. Abdulla, L. S. Chua, N. Najim, M.M. Zain and S. Hamdan. Molecules., 16, 3433(2011), DOI: 10.3390/molecules 16043433

8. S. Park, S. Chung, K.M. Kim, K.C. Jung, C. Park, E.R. Hahm and C.H. Yang. Biochimicaet Biophysica Acta (BBA), General Subjects., 1670, 217(2004), DOI: 10.1021\%2Fbi901913a

9. H. Matsuda, S. Tewtrakul, T. Morikawa, A. Nakamura and M. Yoshikawa. Bioorganic \& Medicinal Chemistry., 12, 5891(2004), DOI: 10.1016/j.bmc.2004.08.027

10. H.P.A. Mary, G.K. Susheela, S. Jayasree, A.M. Nizzy, B. Rajagopal and S. Jeeva. Asian Pacific Journal of Tropical Biomedicine., 2, S637(2012), DOI: 10.1016/S2221-1691(12)60288-3

11. T. Masuda, J. Isobe, A. Jitoe and N. Nakatani., 31, 3645(1992), DOI: 10.1016/0031-9422(92)83748$\mathrm{N}$

12. A. Suksamrarn, S. Eiamong, P. Piyachaturawat and J. Charoenpiboonsin J. Phytochemistry, 36, 1505(1994), DOI: $10.1016 /$ S0031-9422(00)89751-4

13. S. Yodkeeree, W. Chaiwangyen, S. Garbisa and P. Limtrakul. Curcumin, 2009.

14. S.N. Garge, R.P. Bansal, M.M. Gupta and S. Kumar. Flavour and Fragrance Journal., 14, 315(1999). DOI: $10.1002 /($ SICI)1099-1026(199909/10)14:5\%3C315::AID-FFJ838\%3E3.0.CO;2-U

15. W. Pothitirat and W. Gritsanapan. Mahidol University Journal of Pharmaceutical Sciences., 32, 23(2005).

16. J. Lee, Y. Jung, J.H. Shin, H.K.Kim, B.C. Moon, D.H. Ryu and G.S. Hwang. Molecules., 19, 9535 (2014), DOI: $10.3390 /$ molecules19079535

17. Anonim, 2008, Daftar Obat Alam, 3th ed., 39 - 172, Ikatan Sarjana Farmasi Indonesia, Pengurus Daerah Jawa Tengah, Semarang.

18. SNI 01-3709-1995 : Rempah-rempah Bubuk

19. KEPMENKES RI No 261/MENKES/SK/IV/2009: Farmakope Herbal Indonesia edisi ke-1.

20. D.T. Santos, P.C. Veggi and M.A.A. Meireles. J. of Food Engeneering., 101(1), 23(2010), DOI: 10.1016/j.jfoodeng.2011.08.022

21. Wijesekera. 1991. The Medicinal Plant Industry. CRC Press, Amazon, Washington D.C.

22. R.K. Toor, G.P. Savage and A. Heeb. Journal of Food Composition and Analysis., 19(1), 20(2006), DOI: $10.1080 / 10440040903073800$

23. Comes and Allen.. Journal of Ecology., 95(5), 1084(2007), DOI: 10.1139/x2012-142

24. M.R.A. Halim, M.S.M.Z. Tan, S. Ismail and R. Mahmud. International Journal of Pharmacy and Pharmaceutical Science., 4, 606(2012).

25. F. Kazemil, N. Zaraghami1, S.F. Aval and A. Monfaredan. African Journal of Biotechnology., 10, 19481(2011), DOI: 10.5897/AJB11.1228

26. P.F. Steffi PF and M. Srinivasan. Journal of PharmTech Research., 6, 842(2014).

27. K. Hazra, R. Kumar, B.K. Sarkar, Y.A. Chowdary, M. Devgan and M. Ramaiah. IJP., 2, 127(2015), DOI: 10.13040/IJPSR.0975-8232.IJP.2(3).127-30

28. G. Jayaprakasha, L.J.M. Rao and K. Sakariah. Trends in Food Science \& Technology., 16, 533(2005), DOI: $10.1016 /$ j.tifs.2005.08.006

29. L. Péret-Almeida, A. Cherubino, R. Alves, L. Dufossé and M. Gloria. Food Research International., 38, 1039(2005), DOI: 10.1016\%2Fj.foodres.2005.02.021

30. I. Jantan, F.C. Saputri, M.N. Qaisar, and F. Buang. Evidence-Based Complementary and Alternative Medicine., 1, 1(2012), DOI: 10.1155/2012/438356

31. V. Govindarajan and W.H. Stahl. Critical Reviews in Food Science \& Nutrition., 12, 199(1980), DOI: 10.1080/10408398009527278

32. B. Cahyono, M.D.K. Huda and L. Limantara. Reaktor., 13, 165(2011), DOI: 10.14710/reaktor.13.3.165-171

33. M. Rafi, L. Wulansari, R. Heryanto, L.K. Darusman, L.W. Lim and T. Takeuchi. Food Analytical Methods., 1-9 (2015), DOI: 10.1007/s12161-015-0110-1

[RJC-3092/2018] 